Brazilian Journal
of Chemical
Engineering

\title{
PORE BLOCKING MECHANISM FOR THE RECOVERY OF MILK SOLIDS FROM DAIRY WASTEWATER BY ULTRAFILTRATION
}

\author{
V. B. Brião ${ }^{1 *}$ and C. R. G. Tavares ${ }^{2}$ \\ ${ }^{1}$ Faculty of Engineering and Architecture, Food Engineering Department, Phone: + (55) 5433168269 , \\ University of Passo Fundo, BR 285 Road, Km 171, Zip Code: 99052-900, PO Box 611, Passo Fundo - RS, Brazil. \\ E-mail: vandre@upf.br \\ ${ }^{2}$ State University of Maringá, Chemical Engineering Department, Maringá - PR, Brasil. \\ E-mail: celia@deq.uem.br.
}

(Submitted: August 24, 2011 ; Revised: November 21, 2011 ; Accepted: December 12, 2011)

\begin{abstract}
This paper evaluates the pore blocking mechanism of two ultrafiltration membranes with different geometries (tubular and spiral wound) when dairy wash water is filtered. The work evaluated the effect of transmembrane pressure and the cross-flow velocity with a $3^{2}$ experimental design using classical Hermia's models and the resistance-in-series model. The resistance-in-series analysis identified external fouling on the surface of both membranes, but the tubular membrane showed higher reversible fouling, while the reversible and irreversible resistances of the spiral wound membrane averaged $41 \%$ and $45 \%$, respectively. Cake formation is the model that best represents ultrafiltration in the spiral wound membrane at all transmembrane pressures and cross-flow velocities. In the tubular membrane, at the lowest cross-flow velocity $\left(0.79 \mathrm{~m} . \mathrm{s}^{-1}\right)$, the cake formation model fitted the experimental data best. However, at higher cross-flow velocities (1.42 and $2.23 \mathrm{~m} \cdot \mathrm{s}^{-1}$ ), the best fit of flux data was obtained with the complete pore blocking model. In addition, the tubular membrane apparently had a two-step pore blocking: "pore blocking" as the initial governing mechanism followed by "cake formation".
\end{abstract}

Keywords: Membrane; Fouling; Modelling; Effluent.

\section{INTRODUCTION}

Sanitation of facilities in the dairy industry includes washing of silos, tubes, tanks, pasteurizers, and equipment, resulting in large volumes of wastewaters with high organic load (Brião and Tavares, 2007; Baskaran et al., 2003; Vourch et al., 2005). In some cases, each liter of processed milk can produce up to 10 liters of wastewater, sent to the end-of-pipe treatment (Vourch et al., 2005). Losses are estimated to vary from $1 \%$ to $3 \%$ of the milk volume received (Vourch et al., 2008).

The cleaning of equipment starts with rinsing, which carries approximately $80 \%$ of the total organic load produced by the dairy industry. This wash water consists of a milk liquor diluted in water, high in fat, carbohydrates (lactose), proteins and some salts
(Brião, 2000). The recovery of these nutrients from this wash water could be an excellent environmental and economic alternative, removing them from the liquid stream and reducing the organic load of the wastewater (which is sent to treatment or discharged into the water body). Membrane separation processes can be used for this purpose.

Ultrafiltration is a membrane separation process in which a macromolecular solution is forced against a membrane that allows the solvent to pass through while retaining the macromolecules on the highpressure side. Ultrafiltration has a variety of applications, including the purification of drinking water, the treatment of industrial wastes, and the processing of milk and juices (Peppin and Elliot, 2001). In the ultrafiltration (UF) of dairy wash water, the retentate (containing the nutrients) could be used

*To whom correspondence should be addressed 
as production input (dulce de leche, milk-based beverages, powder products) and the organic load of the permeate would decrease by $75 \%$, cutting down the costs of wastewater treatment. Rejection by ultrafiltration membranes can be as high as $97 \%$ for proteins and 93\% for fat (Brião and Tavares, 2007a).

In UF, in addition to membrane rejection, the permeate flux is the variable of economic importance because the estimate of the necessary filtration area is based on it. However, the main problem of membrane techniques is the reduction of permeate flux with time due to membrane fouling, which also produces changes in selectivity and decreases the overall process productivity (Argüello et al., 2002). In UF, there is a rapid permeate flux decrease during the early period of filtration, followed by a long and gradual flux decline towards a steady or nearly steady-state limit value (Barros et al., 2003; Song, 1998; Boxtel et al., 1991).

In UF, the flux decrease is caused by concentration polarization and fouling. Concentration polarization causes a rapid drop in flux, while fouling causes a gradual, long-term decline (Jonsson and Trägardh, 1990). Membrane fouling is due to the deposition and accumulation of particles on the membrane surface and/or the crystallization and precipitation of small molecules on the membrane surface and in the membrane pores. The nature and extent of fouling depend on the characteristics of the solute and on solute/membrane interactions (Cheryan, 1998). Operating conditions also have a direct effect on the extension of polarization concentration and fouling phenomena, such as the transmembrane pressure (TMP) and cross-flow velocity. Larger cross-flow velocities induce turbulence, increase the shear stress in the laminar region and reduce the concentration polarization. Although the TMP is the driving force for permeation, the flux increases with pressure up to a limiting value $\left(\mathrm{TMP}_{\mathrm{lim}}\right)$, which depends on the physical properties of the suspension to be filtered and on the cross-flow velocity (Barros et al., 2003). At low TMP, the flux is governed by the rate at which solvent passes through a porous material (Darcy's Law). At higher TMP, the flux becomes independent of pressure due to concentration polarization. For optimal flux, a TMP at the point at which flux levels off is usually chosen.

When dairy solutions are filtered, one of the main contributions to fouling is the adsorption of proteins onto the membrane surface and in the membrane pores (Argüello et al., 2002). Understanding how this phenomenon takes place helps predict the permeate flux and, consequently, assess the economic value of the process.

The aim of the present paper was to submit wash waters from the dairy industry to ultrafiltration in order to recover nutrients and to assess the pore blocking mechanisms that occur during the process.

\section{MATHEMATICAL MODELS}

\section{Resistance-In-Series Analysis}

The resistance-in-series model has been used to evaluate fouling in the membrane separation process (Blanpain and Lalande, 1997; Gésan-Guisiou, 1999; Merin and Shomer, 1999; Choi et al., 2005; Timmer et al., 1997; Chang and Kim, 2005; Huisman et al., 1998). According to Darcy's Law:

$\mathrm{J}=\frac{\mathrm{TMP}}{\mu \cdot \mathrm{R}}$

where $J$ is the permeate flux, TMP is the transmembrane pressure, $\mu$ is the viscosity of the permeate, and $\mathrm{R}$ is the total resistance. When dairy wash water is filtered, Equation (1) becomes:

$J=\frac{T M P}{\mu .\left(R_{m}+R_{r}+R_{\text {ir }}\right)}$

$\mathrm{R}_{\mathrm{m}}$ is the hydraulic resistance of the clean membrane; the additional resistance is separated into two parts: $R_{\text {ir }}$, the fouling hydraulic resistance (fouling is defined as irreversible deposition onto the membrane surface or in the membrane matrix, such as adsorption, internal pore blocking); and $R_{r}$ is the hydraulic resistance due to reversible phenomena (concentration polarization and/or reversible deposit) (Gésan-Guisiou, 1999).

$R_{m}$ and $R_{i r}$ were calculated from the pure water permeate flux.

$\mathrm{R}_{\mathrm{m}}=\frac{\mathrm{TMP}}{\mu_{\mathrm{w}} \cdot \mathrm{J}_{\mathrm{w}}}$

where $J_{w}$ is the initial water permeate flux. After rinsing the membrane $\left(R_{r}=0\right)$, the pure water permeate flux $\left(\mathrm{J}_{\mathrm{w}}\right)$ indicates the $\mathrm{R}_{\mathrm{ir}}$ resistance:

$$
\mathrm{R}_{\mathrm{ir}}=\frac{\mathrm{TMP}}{\mu_{\mathrm{w}} \cdot \mathrm{J}^{\prime}{ }_{\mathrm{w}}}-\mathrm{R}_{\mathrm{m}}
$$

The sum of $R_{m}, R_{r}$ and $R_{i r}$, which make up total resistance, can indicate which terms play a major role in the flux decline, as well as reveal whether the adhesion of solutes occurs preferably in the external region $\left(R_{r}\right.$ at a higher ratio) or in the inner part of the membrane-within the pores $\left(\mathrm{R}_{\mathrm{ir}}\right.$ at a higher ratio). 


\section{Membrane Pore Blocking Models}

During filtration, slurry particles are carried by the liquid towards the filter membrane and then deposit on the membrane surface to form a filter cake or block in the pores of the membrane. Both cases result in the increase of filtration resistance and in the attenuation of the filtration rate. In order to describe the blocking phenomena in filtration, four kinds of blocking models (Figure 1) have been proposed.

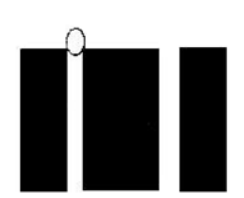

(A)

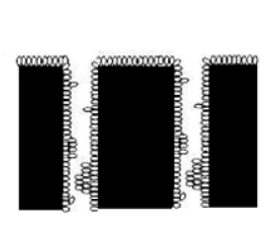

(B)

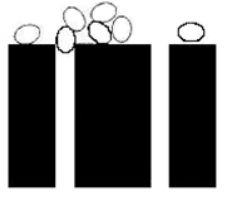

(C)

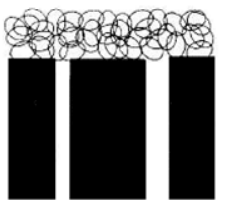

(D)
Figure 1: Schematic drawing of the fouling mechanisms assumed: (A) complete blocking; (B) internal pore blocking; (C) intermediate blocking; (D) cake formation (Source: Bowen et al., 1995).

A mathematical model (Equation (5)) was presented by Hermia (1982) to describe the permeate flux decline. This model is based on classical constant-pressure dead-end filtration equations. The constant $\mathrm{n}$ depends on the pore blocking mechanism involved in the process.

$$
\frac{\mathrm{d}^{2} \mathrm{t}}{\mathrm{dV}^{2}}=\mathrm{k}\left(\frac{\mathrm{dt}}{\mathrm{dV}}\right)^{\mathrm{n}}
$$

\section{Complete Pore Blocking $(n=2)$}

The size of the particles is larger than that of the membrane pore; in this case, particles deposit on the membrane surface and block the entrances of membrane pores completely with no overlapping particles. The decrease in the number of membrane pores increases the filtration resistance (Hwang and Lin, 2002).

\section{Internal Pore Blocking $(\mathrm{n}=\mathbf{1 , 5})$}

The basic assumption of this model is that the internal volume of the pores decreases proportionally to the permeate volume due to deposition or adsorption of microsolutes on the pore walls (Jaffrin et al., 1997). Material not rejected by the pore entrance is adsorbed or trapped on the pore wall or in the membrane support, thus leading to a decrease in pore volume.

\section{Intermediate Pore Blocking $(n=1)$}

Each particle arriving at the membrane settles on another particle, which had arrived previously and was already blocking some pore, or directly blocks some membrane area; the probability of landing upon particles already on the surface is taken into account (Field et al., 1995; Jacob et al., 1998).

\section{Cake Formation $(\mathbf{n}=\mathbf{0})$}

Each particle locates on others that have already arrived and are blocking some pores and there is no room for directly obstructing any membrane area (Jacob et al., 1998). The basic assumption is that the cake resistance is proportional to the cumulative filtered volume (Jaffrin et al., 1997).

Many researchers have used the adaptation of Hermia's model to evaluate the flux decline in deadend filtration and cross-flow filtration (Bowen et al, 1995; Hwang and Lin, 2002; Herrero et al., 1997; Jacob et al., 1998; Jaffrin et al., 1997; Jonsson et al., 1996; Rezaei et al. 2011; Yazdanshenas et al., 2010; Li et al., 2010; Vela et al., 2008, Ye et al., 2005; Arnot et al., 2000). However, Field et al. (1995) modified Hermia's model (1982) for cross-flow filtration by adding a term that represents convective removal (Equation (6)).

$-\frac{\mathrm{dJ}}{\mathrm{dt}} \cdot\left(\mathrm{J}^{\mathrm{n}-2}\right)=\mathrm{k}\left(\mathrm{J}-\mathrm{J}^{*}\right)$

The term $\mathrm{J}^{*}$ can be considered to be a critical flux that should not be exceeded if fouling is to be avoided; $\mathrm{k}$ and $\mathrm{n}$ are a phenomenological coefficient and a general index, respectively, both depending on the fouling mechanism (Field et al., 1995).

After some manipulation, Field et al. (1995) obtained equations for different pore blocking mechanisms (Table 1). In these equations, where $\mathrm{k}_{\mathrm{a}}$, $\mathrm{k}_{\mathrm{b}}, \mathrm{k}_{\mathrm{c}}$ and $\mathrm{k}_{\mathrm{d}}$ are constants of the models. $\mathrm{J}_{0}$ is the initial permeate flux $(\mathrm{t}=0) ; \varepsilon_{0}$ is the membrane surface porosity (clean membrane); $\mathrm{k}_{\mathrm{c}}$ is the constant of Hermia's model for intermediate blocking; $\mathrm{A}$ is the membrane surface area; $\sigma$ represents the blocked membrane area per unit permeate volume; $\alpha$ is a parameter characterizing the fouling potential of the solution for the cake filtration model; $\mathrm{k}_{\mathrm{d}}$ is the cake filtration constant relating mass to volume; $\mathrm{R}_{\mathrm{m}}$ is the clean membrane resistance. 
Table 1: Equations for membrane fouling models in cross-flow ultrafiltration

\begin{tabular}{|l|c|c|c|c|}
\hline $\begin{array}{l}\text { Pore blocking } \\
\text { mechanism }\end{array}$ & $\mathbf{n}$ & Final Equation & Constant & $\begin{array}{c}\text { Equation } \\
\text { number }\end{array}$ \\
\hline $\begin{array}{l}\text { Complete pore } \\
\text { blocking }\end{array}$ & 2 & $\mathrm{~J}=\mathrm{J}^{*}+\left(\mathrm{J}_{0}-\mathrm{J}^{*}\right) \mathrm{e}^{\left(-\mathrm{k}_{\mathrm{a}} \cdot \mathrm{t}\right)}$ & $\mathrm{k}_{\mathrm{a}}=\frac{\mathrm{J}_{0} \cdot \sigma}{\varepsilon_{0}}$ & $(7)$ \\
\hline $\begin{array}{l}\text { Internal pore } \\
\text { blocking }\end{array}$ & 1,5 & $\frac{1}{\mathrm{~J} / 2}=\frac{1}{\mathrm{~J} / 2}+\mathrm{k}_{\mathrm{b}} \cdot \mathrm{t}$ & $\mathrm{k}_{\mathrm{b}}=\frac{\mathrm{k}_{1}}{2} \cdot \mathrm{A}^{1 / 2}$ & $\mathrm{k}_{\mathrm{c}}=\sigma$ \\
\hline $\begin{array}{l}\text { Intermediate } \\
\text { pore blocking }\end{array}$ & 1 & $\mathrm{k}_{\mathrm{c}} \cdot \mathrm{t}=\frac{1}{\mathrm{~J}^{*}} \ln \left(\frac{\mathrm{J}}{\mathrm{J}_{0}} \cdot \frac{\left(\mathrm{J}_{0}-\mathrm{J}^{*}\right)}{\left(\mathrm{J}-\mathrm{J}^{*}\right)}\right)$. & $(9)$ \\
\hline Cake formation & 0 & $\mathrm{k}_{\mathrm{d}} \cdot \mathrm{t}=\frac{1}{\mathrm{~J}^{* 2}}\left[\ln \left(\frac{\mathrm{J}_{0}}{\mathrm{~J}} \frac{\left(\mathrm{J}_{0}-\mathrm{J}^{*}\right)}{\left(\mathrm{J}-\mathrm{J}^{*}\right)}\right)\right]-\mathrm{J}^{*}\left(\frac{1}{\mathrm{~J}}-\frac{1}{\mathrm{~J}_{0}}\right)$ & $\mathrm{k}_{\mathrm{d}}=\frac{\alpha \cdot \mathrm{k}_{\mathrm{t}}}{\mathrm{J}_{0} \mathrm{R}_{\mathrm{m}}}$ & $(10)$ \\
\hline
\end{tabular}

\section{MATERIAL AND METHODS}

\section{Experiments}

The dairy wash water was simulated by diluting whole milk powder in water at a concentration of 2 g. $\mathrm{L}^{-1}$. This concentration was tested so that the chemical oxygen demand (COD) was close to $2,000 \mathrm{mg} . \mathrm{L}^{-1}$, similar to that of dairy wastewater, as observed by Brião (2000). Figure 2 illustrates the ultrafiltration apparatus.

The experiment was carried out in a pilot module provided by WGM Systems in Brazil. The pilot module consisted of a stainless steel tank with $18 \mathrm{~L}$ capacity from which the simulated wastewater was fed to and driven by a pneumatic pump through the membrane, separating the permeate from the retentate. The permeate was collected on a semianalytical balance accurate to two decimal places
(Marte brand, model AS2000C) to measure the permeate flux, while the retentate was recirculated back to the feed tank. The equipment had a tubular heat exchanger in the circulation line of the retentate and cold water $\left(2^{\circ} \mathrm{C}\right.$ to $\left.4^{\circ} \mathrm{C}\right)$ was recirculated with the aid of a thermostat bath (Manufacturer: Marconi, Model 184) to maintain the temperature in the range of $23^{\circ} \mathrm{C} \pm 1{ }^{\circ} \mathrm{C}$. All flow lines were recycled to the tank to keep a constant feed concentration.

Two membranes were used. The first one was a tubular membrane (HFM - 180 - Koch Membrane Systems Inc., MWCO $80 \mathrm{kDa}), 1.27 \mathrm{~cm}(0.5 \mathrm{inch})$ in diameter, made of polyvinylidenefluoride (PVDF), with an area of $166 \mathrm{~cm}^{2}$; the second membrane was made of polyethersulfone (PES) in a spiral wound configuration (HFM - 131 - Koch Membrane Systems Inc., MWCO 5kDa), $2.54 \mathrm{~cm}$ (1 inch) in diameter and with an effective filtration area of $0.28 \mathrm{~m}^{2}$.

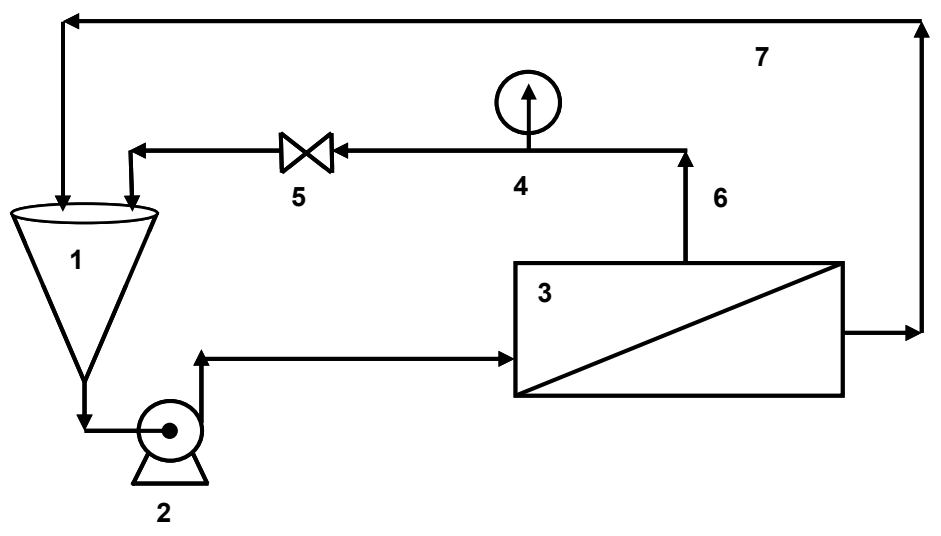

1. Feed tank;

2. pneumatic pump;

3. membrane;

4. manometer;

5. diaphragm valve;

6. retentate;

7. permeate.

Figure 2: Schematic diagram of ultrafiltration equipment. 
The pure water flux $\left(\mathrm{J}_{\mathrm{w}}\right)$ was measured before each experiment with distilled water. After dairy wash water filtration, the membrane surface was washed in order to remove reversible fouling without disturbing the irreversible membrane fouling (Blanpain and Lalande, 1997) and a new pure water flux was measured to obtain $\mathrm{J}_{\mathrm{w}}{ }_{\mathrm{w}}$. The resistances were obtained according to Equation (1) - (4).

\section{Experimental Design}

Two independent variables (pressure and crossflow velocity) at three different levels $\left(3^{2}\right)$ were applied to each membrane (tubular and spiral wound). Table 2 shows the experimental design matrix with the pressures and cross-flow velocities applied to each membrane. The experiments were conducted in duplicate and in random order.

Table 2: Transmembrane pressure (TMP) and cross-flow velocity of the experimental design

\begin{tabular}{|l|c|c|}
\hline Membrane & $\begin{array}{r}\text { TMP } \\
\text { (kPa) }\end{array}$ & $\begin{array}{c}\text { Cross-flow velocity } \\
\text { (m.s }^{-1} \text { ) }\end{array}$ \\
\hline Tubular PVDF & 98 & 0.79 \\
80 kDa & 196 & 1.42 \\
& 294 & 2.23 \\
Spiral wound & 98 & 0.15 \\
PES 5 kDa & 196 & 0.27 \\
& 294 & 0.44 \\
\hline
\end{tabular}

The cross-flow velocities in each system were determined according Equation (11):

$\mathrm{v}=\frac{\mathrm{Q}}{\mathrm{A}}$

where the area (A) is that perpendicular to the flow; $\mathrm{V}$ is the average cross-flow velocity; $\mathrm{Q}$ is the retentate flowrate; for the spiral wound membrane, the area is that perpendicular to the flow and is equal to the net channel thickness multiplied by the channel width. The net channel thickness is equal to the gross channel thickness minus the volume displaced by the mesh spacer per unit area (Clarke and Heath, 1997).

\section{Analysis of the Pore Blocking Mechanism}

The resistance-in-series model was used to identify the place (membrane surface or internal pore) of fouling. The physical properties of the permeate (specific weight and viscosity) were considered to be the same as those of water because the permeate was a dilute solution. Total resistance $(\mathrm{R})$, irreversible resistance $\left(\mathrm{R}_{\mathrm{ir}}\right)$ and reversible resistance $\left(R_{r}\right)$ were determined.

To identify the fouling mechanism during the ultrafiltration of the dairy wash water, the parameters $\mathrm{k}$ and $\mathrm{n}$ were estimated according to the nonlinear regression optimization procedure, using MATLAB ${ }^{\circledR}$ software. Four optimization runs were performed sequentially for each set $\mathrm{J} \times \mathrm{t}$ by assigning $(\mathrm{n}=0,1.0,1.5,2.0)$, corresponding to the steadystate value $\mathrm{J}^{*}$ already observed experimentally (last permeate flux measured). The sum of the squares of the residuals between numerical predictions and experimental data was the criterion used to establish the fouling mechanism (Barros et al., 2003).

\section{RESULTS AND DISCUSSION}

Figure 3 shows the permeate flux for the tubular PVDF $80 \mathrm{kDa}$ MWCO membrane and Figure 4 shows the flux curves for the PES $5 \mathrm{kDa}$ spiral wound membrane.

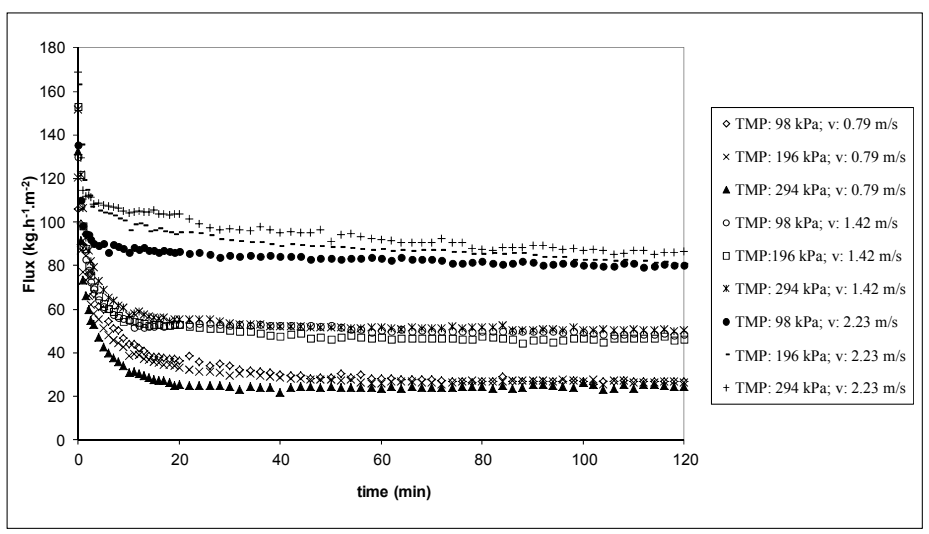

Figure 3: Flux decline versus time for the tubular membrane at different TMP and cross-flow velocities 


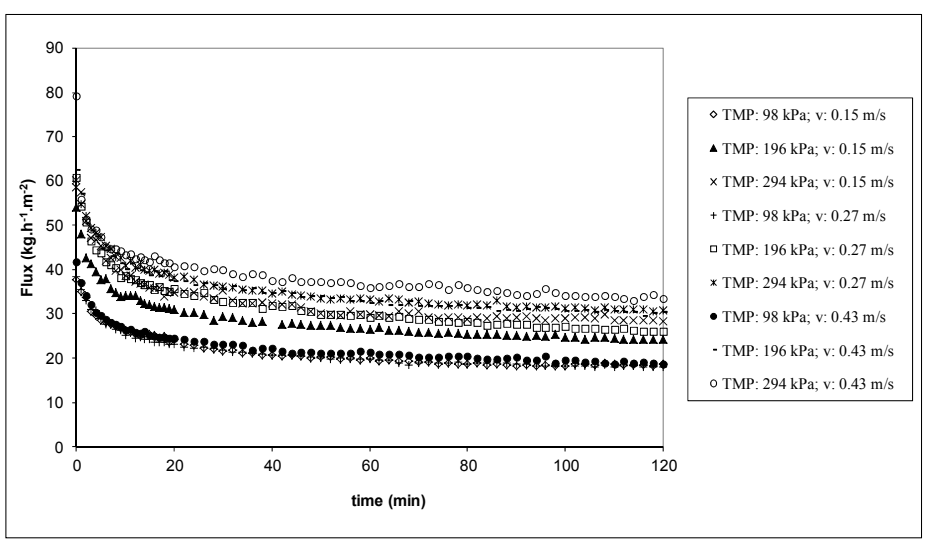

Figure 4: Flux decline versus time for the spiral wound membrane at different TMP and cross-flow velocities

Figure 3 shows three distinct flux levels after 120 min of filtration, with three different cross-flow velocities. In the early filtration period, higher pressures increased the flux. However, as time went on, pressure also increased fouling, heightening resistance, thereby reducing the flux.

Unlike the tubular membrane flux, that of the spiral wound membrane was reached at higher TMP $(294 \mathrm{kPa})$ and at a higher cross-flow velocity $\left(0.44 \mathrm{~m} \cdot \mathrm{s}^{-1}\right)$. However, the increase in resistance was higher than the flux increase in such a way that no proportional flux was obtained by doubling the pressure and cross-flow velocity.

Permeated flux showed a typical ultrafiltration behavior for both membranes, with a sharp decline in the first minutes, followed by a slower decline. The initial sharp decrease in flux was attributed to protein adsorption and the subsequent slower decrease ascribed to the effects of concentration polarization. Actually, protein adsorption occurs within a very short time in the ultrafiltration of milk (James et al. 2003).
A preliminary analysis of the extent of (reversible and irreversible) fouling could be made by comparing the initial permeate flux $\left(\mathrm{J}_{0}\right)$ and the steady-state permeate flux $\left(\mathrm{J}^{*}\right)$. The tubular membrane has a higher molecular weight cutoff MWCO $(80 \mathrm{kDa})$ than the spiral wound membrane $(5 \mathrm{kDa})$ and thus the tubular membrane showed a higher initial permeate flux. This relationship was near 0.5 for the spiral wound membrane (under all experimental conditions) and the value was close to $0.2\left(\mathrm{v}=0.7 \mathrm{~m} . \mathrm{s}^{-1}\right)$ and $0.5\left(\mathrm{v}=2.23 \mathrm{~m} \cdot \mathrm{s}^{-1}\right)$, showing that fouling is higher in the tubular membrane.

\section{Resistance-In-Series Model}

Figures 5 and 6 show the increase in total resistance $(\mathrm{R})$ throughout the filtration period for the tubular and spiral wound membranes, respectively. Total resistance was highest under higher pressure $(294 \mathrm{kPa})$ and at lower cross-flow velocity, as the rise in the driving force for movement did not lead to a proportional increase in permeate flux.

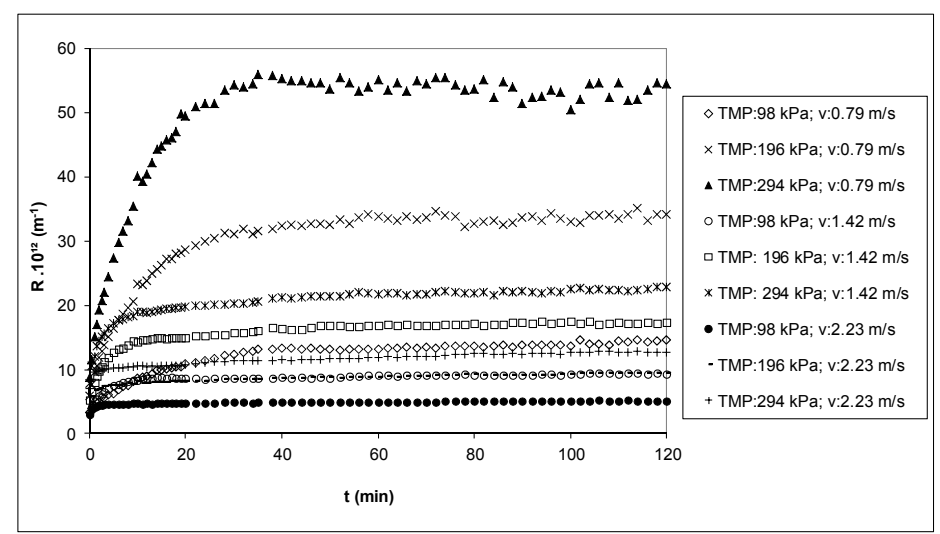

Figure 5: Increase of total resistance during ultrafiltration of model dairy wash water with the tubular membrane 


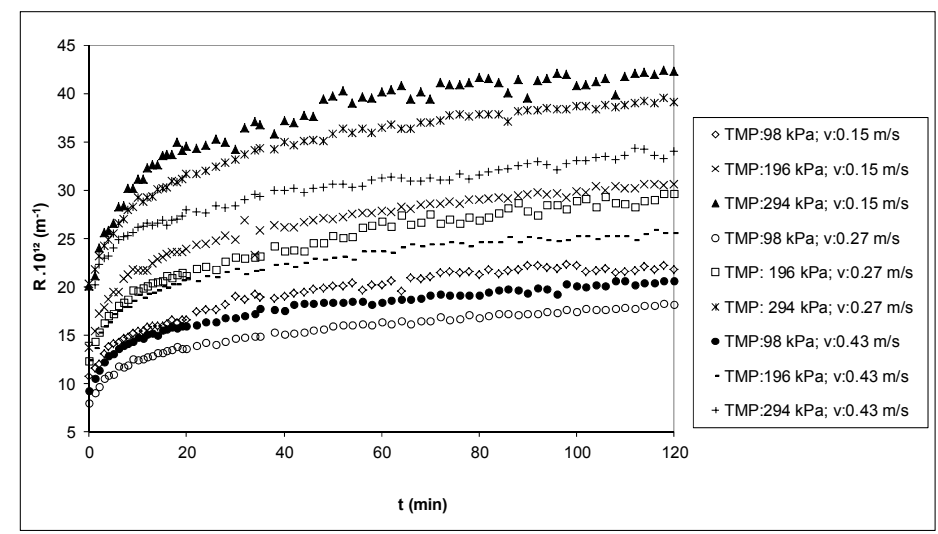

Figure 6: Increase of total resistance during ultrafiltration of model wastewater with the spiral wound membrane

Examination of the theoretical resistance curves indicates that cases in which the resistance increases with an increasing slope may be described by internal fouling models and those in which it increases with a decreasing slope may be described by the external cake filtration model (Tracey and Davis, 1994).

In fact, depending on solute size and membrane pore size interactions, the curves can initially be concave upwards (internal deposit), but as the pores decrease their diameter, there occurs external deposit (Bowen et al., 1995). Nevertheless, Figures 5 and 6 show that the curves are concave downwards under all conditions tested, demonstrating that there was external pore blocking only.

The molecular sizes of milk components are shown in Table 3. This information is useful to confirm external pore blocking because the milk component sizes are greater than those of the membrane pores, except for the calcium ion. However, the concentration of $\mathrm{Ca}^{2+}$ is low (about 40 $\mathrm{mg} . \mathrm{L}^{-1}$ ) in dairy wash water, not being a problem in ultrafiltration experiments. However, these data alone do not allow the determination of which mechanism is actually at play in pore blocking.

\section{Table 3: Molecular sizes of milk components}

\begin{tabular}{|l|c|c|}
\hline Component & Molecular weight & Diameter (nm) \\
\hline Water & 18 & 0.3 \\
Calcium ion & 40 & 0.4 \\
Lactose & 342 & 0.8 \\
$\alpha$-lactalbumin & 14500 & 3.0 \\
$\beta$-lactalbumin & 36000 & 4.0 \\
Blood serum albumin & 69000 & 5.0 \\
Casein micelles & $107-109$ & $25-130$ \\
Fat & - & $2000-10000$ \\
\hline
\end{tabular}

Source: James et al. (2003) apud Cheryan and Alvarez (1995)
Table 4 presents the means for reversible and irreversible membrane total resistance. The tubular membrane resistance was lower than that of the spiral wound membrane by around 15 times (a direct effect of the larger pore size). The spiral wound membrane exhibited a larger tendency towards irreversible fouling (about $45 \%$ of total resistance) than the tubular membrane (about $17 \%$ of total resistance). On the other hand, $\mathrm{R}_{\mathrm{r}}$ was higher in the tubular membrane ultrafiltration (mean of $80 \%$ ) than in that of the spiral wound membrane (mean of 17\%). Blanpain and Lalande (1997) also found that the external reversible resistance contributed to a greater extent (above $80 \%$ ) to the total resistance in the microfiltration of beer, but that there was a transition from internal pore blocking to cake formation.

Table 5 shows the characteristics of the wash water. Irreversible resistance is caused by strong adsorption onto the membrane surface. The intensity of this phenomenon depends on the interactions between solute and membrane. Most of the problems encountered in membrane filtration are physicochemical phenomena. They stem from differences in the formation of different types of bonds such as ion-ion, ion-dipole and dipole-dipole bonds, hydrogen bonds being the latter type (Matthiasson and Sivik, 1980).

It is well known that calcium phosphate plays an important role in the fouling of membranes. Both amorphous and crystalline calcium phosphates form complexes within milk proteins and the protein precipitates together with calcium phosphate (Boxtel et al., 1991). Precipitation is the main mechanism whereby calcium phosphate participates in membrane fouling, but Table 5 shows a low concentration of phosphorus and calcium in dairy wash water, indicating that this route is not the main contribution to membrane fouling. 
Table 4: Average resistance-in-series (membrane, irreversible and reversible) in the ultrafiltration of dairy wash water

\begin{tabular}{|l|c|c|c|c|}
\hline Membrane & $\mathbf{R} \cdot 10^{-11}\left(\mathbf{m}^{-1}\right)$ & $\mathbf{R}_{\mathbf{m}} \cdot \mathbf{1 0}^{-11}\left(\mathbf{m}^{-1}\right)$ & $\mathbf{R}_{\mathbf{i r} \cdot 10^{-11}}\left(\mathbf{m}^{-1}\right)$ & $\mathbf{R}_{\mathbf{r}} \cdot \mathbf{1 0}^{-11}\left(\mathbf{m}^{-1}\right)$ \\
\hline $\begin{array}{l}\text { Tubular PVDF } \\
\text { 80 kDa MWCO }\end{array}$ & $162.2 \pm 93.5$ & $2.7 \pm 0.3$ & $22.0 \pm 10.1$ & $137.5 \pm 88.3$ \\
\hline $\begin{array}{l}\text { Spiral wound PES } \\
\text { 5 kDa MWCO }\end{array}$ & $299.1 \pm 77.6$ & $41.9 \pm 5.4$ & $135.7 \pm 44.5$ & $121.5 \pm 33.6$ \\
\hline
\end{tabular}

Table 5: Characteristics of dairy wash water

\begin{tabular}{|c|c|c|c|c|c|c|}
\hline $\begin{array}{c}\text { Turbidity } \\
\text { (FAU) }\end{array}$ & $\begin{array}{c}\text { COD } \\
\left(\mathbf{m g . L}^{-1}\right)\end{array}$ & $\begin{array}{c}\text { Protein } \\
\left(\mathbf{m g . L}^{-1}\right)\end{array}$ & $\begin{array}{c}\text { Lactose } \\
\left(\mathbf{m g . L}^{-1}\right)\end{array}$ & $\begin{array}{c}\text { Oil and grease } \\
\left(\mathbf{m g . L}^{-\mathbf{1}}\right)\end{array}$ & $\begin{array}{c}\text { Phosphorus } \\
\left(\mathbf{m g . L}^{-\mathbf{1}}\right)\end{array}$ & $\begin{array}{c}\text { Calcium } \\
\left(\mathbf{m g . L}^{-1}\right)\end{array}$ \\
\hline 2134.2 & 2241.2 & 416.5 & 815.2 & 611.0 & 12.1 & 42.2 \\
\hline
\end{tabular}

Baudry et al. (2002) used advanced techniques such as ATR-FTIR (attenuated total reflectance Fourier transform infra-red) and EDX (energy dispersive X-ray) spectroscopy coupled with SEM (scanning electron microscopy) to identify the chemistry of the fouling layer in the ultrafiltration of skimmed milk. The authors identified the adsorption of all milk components (lactose, salts, proteins), even under static conditions. However, after rinsing, lactose and salts were removed, but proteins remained adhered to the membrane. Hence, lactose and salts play a role in reversible resistance, whereas proteins take part in both resistances (reversible and irreversible).

James et al. (2003) conducted a microstructural study of membranes fouled by milk. They used SEM images to identify the irreversible adsorption of protein onto the membrane and found that the internal fouling of microfiltration membranes can be attributed to the interaction between protein molecules or clusters and the membrane polymer, coupled with protein-protein interactions, thus forming agglomerates. This protein adsorbed onto the membrane surface is the whey protein fraction other than casein micelles.

Table 6 contains the analysis of variance (ANOVA), showing the effect of transmembrane pressure and of cross-flow velocity on the total resistance of the tubular membrane filtration. Both variables (TMP and v) proved to have an effect on the total resistance of filtration, with TMP and $\mathrm{v}$ interaction $\left(\mathrm{p}<0.05\right.$ for $\left.\mathrm{TMP}^{*} \mathrm{v}\right)$ in such a way that TMP increases the resistance further when lower cross-flow velocities are used. The effects of TMP and $\mathrm{v}$ on the experimental resistances obtained from the tubular membrane are shown in Figure 7.

Pressure produced an effect on both resistances (irreversible and reversible) and, consequently, on the total resistance. Note that Figure 7 (a) is quite similar to Figure 7 (c), as reversible resistance contributed the most to the total resistance of the process (about $80 \%$ ). The optimal point for working with the tubular membrane is that at which the total resistance of filtration is minimized, i.e., by using a cross-flow velocity of $2.23 \mathrm{~m} . \mathrm{s}^{-1}$. The use of higher pressures increases the flux at the beginning of the process (Figure 3), but it also increases filtration resistances (both irreversible and reversible); therefore, it is not possible to obtain flux increases with higher pressures.

The ANOVA also demonstrated that the transmembrane pressure produced an effect on both resistances (irreversible and reversible). This is because higher pressures take the solutes to the membrane (into the boundary layer) at a higher concentration, in addition to forcing the solutes against the membrane, thus enhancing the irreversible adsorption of these compounds.

Table 6: ANOVA for evaluation of the effect of transmembrane pressure and cross-flow velocity on total resistance of tubular membrane

\begin{tabular}{|l|c|c|c|r|r|}
\hline & Sum of Squares & Degrees of freedom & Mean Square & \multicolumn{1}{|c|}{ F } & \multicolumn{1}{c|}{ p } \\
\hline TMP & $1.24 \mathrm{E} 27$ & 2 & $6.21 \mathrm{E} 26$ & 193.651 & $<1 \mathrm{E}-6$ \\
V & $2.04 \mathrm{E} 27$ & 2 & $1.02 \mathrm{E} 27$ & 318.262 & 0.000005 \\
TMP*v & $5.98 \mathrm{E} 26$ & 4 & $1.49 \mathrm{E} 26$ & 46.607 & \\
Error & $2.89 \mathrm{E} 25$ & 9 & $3.21 \mathrm{E} 24$ & & \\
\hline
\end{tabular}

TMP: transmembrane pressure; $v$ : cross-flow velocity; $\mathrm{p}<0.05$ indicates significant effect on total resistance 

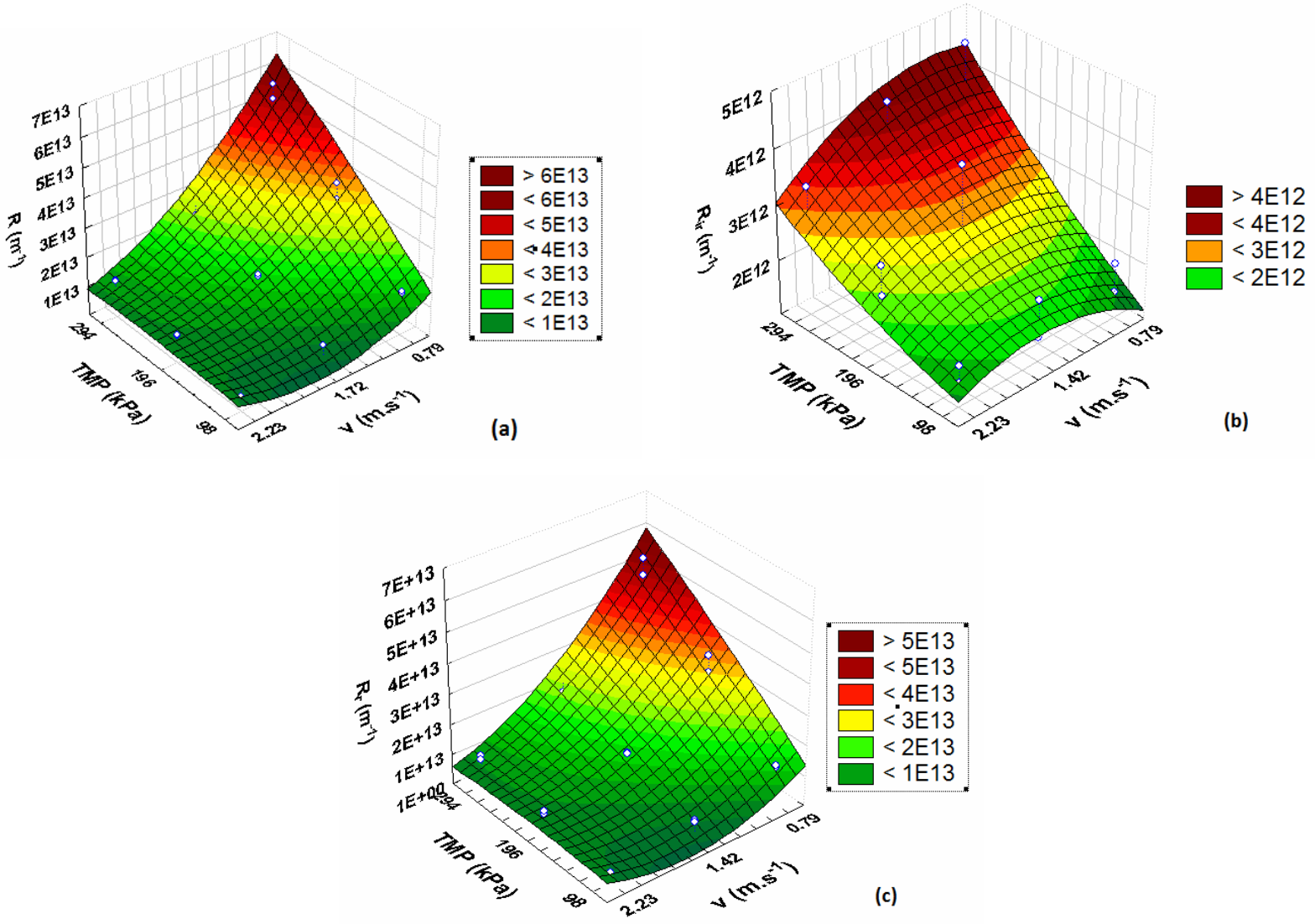

Figure 7: Effect of transmembrane pressure (TMP) and cross-flow velocity (v) on total resistance (a), irreversible resistance (b) and reversible resistance (c) of the tubular membrane

On the other hand, the cross-flow velocity influenced only the reversible resistance. Actually, cross-velocities of $0.79 \mathrm{~m} . \mathrm{s}^{-1}, 1.72 \mathrm{~m} . \mathrm{s}^{-1}$ and $2.23 \mathrm{~m} . \mathrm{s}^{-1}$ increase the Reynolds number (10012, 17997 and 28264), reducing the polarized layer, in addition to increasing the tangential drag of the solute on the membrane surface, reducing the reversible resistance and thus not causing an impact on the irreversible resistance. Some evidence suggests that high shear stress per se does not hinder the physicochemical fouling process, but that it can significantly play down its negative effects (Matthiasson and Sivik, 1980).

Figure 8 shows the effects of transmembrane pressure and cross-flow velocity on the filtration resistances of the spiral wound membrane.

The pressure elevated all filtration resistances and, therefore, no proportional increase in flux was observed. On the other hand, the cross-velocities used $\left(0.15 \mathrm{~m} . \mathrm{s}^{-1}, 0.27 \mathrm{~m} . \mathrm{s}^{-1}, 0.44 \mathrm{~m} . \mathrm{s}^{-1}\right)$ created laminar flow conditions (Reynolds numbers of 285, 514 and 819, respectively). Even though the spiral wound membrane spacer offers some mixing in the circulation channel of the feed stream, increases in velocity did not produce a proportional effect on the reduction of the reversible resistance as occurred with the tubular membrane. Nonetheless, under higher pressure $(294 \mathrm{kPa})$, the total resistance decreased (Figure 8-a) at the highest cross-flow velocity, showing that the effects of TMP and v are combined. This piece of evidence is indicated in Table 7, showing the interaction between TMP and v. Likewise, both TMP and $\mathrm{v}$ had some effect on total resistance $(\mathrm{p}<0.05)$.

Baudry et al. (2002) carried out fouling experiments with milk employing the same spiral wound membrane (HFK 131 - Koch Membrane Systems) as in the present work. They found that irreversible fouling was attached to the membrane even after chemical cleaning. The reason for this was strong protein adsorption and, even when the hydraulic permeability was recovered, traces of proteins were still adsorbed onto the membrane surface. 

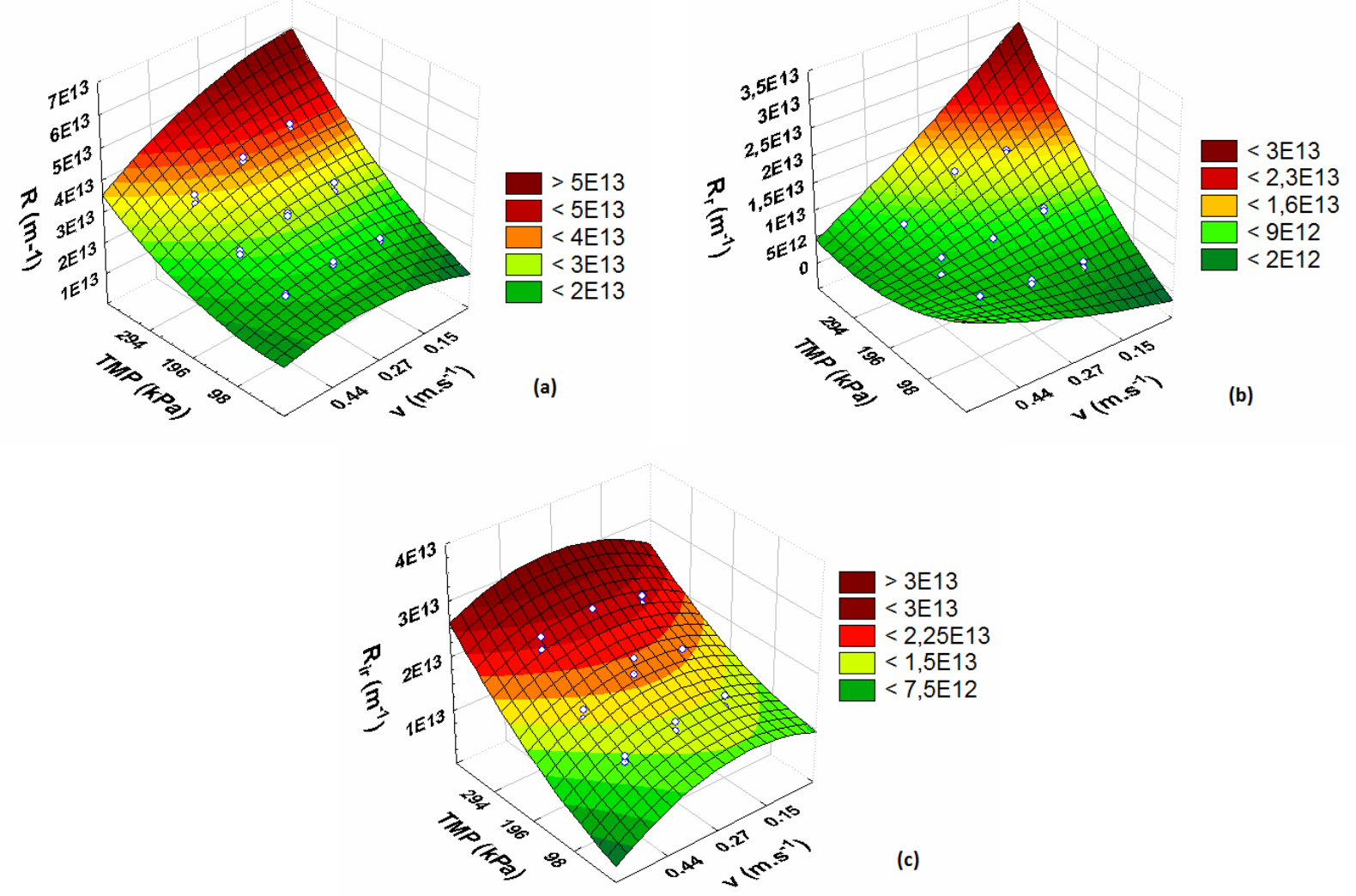

Figure 8: Effect of transmembrane pressure (TMP) and cross-flow velocity (v) on total resistance (a), irreversible resistance (b) and reversible resistance (c) of the spiral wound membrane

Table 7: ANOVA for evaluation of the effect of transmembrane pressure and cross-flow velocity on total resistance of spiral wound membrane

\begin{tabular}{|l|c|c|c|r|r|}
\hline & $\begin{array}{c}\text { Sum of } \\
\text { Squares }\end{array}$ & $\begin{array}{c}\text { Degrees of } \\
\text { freedom }\end{array}$ & $\begin{array}{c}\text { Mean } \\
\text { Square }\end{array}$ & F & p \\
\hline TMP & $1.58 \mathrm{E} 28$ & 1 & $1.58 \mathrm{E} 28$ & 11400.66 & $<1 \mathrm{E}-4$ \\
V & $8.63 \mathrm{E} 26$ & 2 & $4.31 \mathrm{E} 26$ & 311.14 & $<1 \mathrm{E}-4$ \\
TMP* & $7.71 \mathrm{E} 25$ & 2 & $3.85 \mathrm{E} 25$ & 27.79 & 0.0001 \\
Error & $2.58 \mathrm{E} 25$ & 4 & $6.46 \mathrm{E} 24$ & 4.66 & 0.0259 \\
\hline
\end{tabular}

TMP: transmembrane pressure; $\mathrm{v}$ : cross-flow velocity; $\mathrm{p}<0.05$ indicates significant effect on total resistance

\section{Pore Blocking Models}

Table 8 shows the sum of squares for the nonlinear regression of each pore blocking model (Equations (7) through (10)) for the ultrafiltration tests with spiral wound membrane.

Ultrafiltration of model wastewater in the spiral wound membrane presented the same behavior under all of the tested pressure and cross-flow velocity conditions and cake formation was the mathematic model that best represented the process (lowest sum of squares).

Figure 9 shows the result of nonlinear regression for each pore blocking model under $98 \mathrm{kPa}$ and at a cross-flow velocity of $0.15 \mathrm{~m} \cdot \mathrm{s}^{-1}$ (Figure 9 (a)) and under $294 \mathrm{kPa}$ and at $0.44 \mathrm{~m} \cdot \mathrm{s}^{-1}$ (Figure 9 (b)). Note that the internal pore blocking model was the farthest away from the experimental data, showing that internal pore blocking was discrete, or did not occur at all, in the membrane. However, it is also possible to observe in Figure 9 (b) that, although the physical-mathematical model of cake formation yielded the lowest sum of squares, there is a time period $(\mathrm{t}<30 \mathrm{~min})$ in which the experimental data deviate from this model, which possibly indicates more than one pore blocking mechanism. 
Table 8: Sum of squares for the nonlinear regression of each pore blocking model assessed for the spiral wound membrane

\begin{tabular}{|l|c|c|c|c|}
\hline & Cake filtration & $\begin{array}{c}\text { Intermediate } \\
\text { pore blocking }\end{array}$ & $\begin{array}{c}\text { Internal } \\
\text { pore blocking }\end{array}$ & $\begin{array}{c}\text { Complete } \\
\text { pore blocking }\end{array}$ \\
\hline $98 \mathrm{kPa} ; 0.15 \mathrm{~m} . \mathrm{s}^{-1}$ & 30.5 & 52.5 & 292.5 & 75.3 \\
$196 \mathrm{kPa} ; 0.15 \mathrm{~m} \cdot \mathrm{s}^{-1}$ & 67.9 & 124.6 & 470.6 & 136.9 \\
$298 \mathrm{kPa} ; 0.15 \mathrm{~m} . \mathrm{s}^{-1}$ & 59.0 & 113.1 & 535.0 & 111.4 \\
$98 \mathrm{kPa} ; 0.27 \mathrm{~m} . \mathrm{s}^{-1}$ & 33.5 & 71.1 & 315.0 & 84.1 \\
$196 \mathrm{kPa} ; 0.27 \mathrm{~m} . \mathrm{s}^{-1}$ & 84.6 & 147.2 & 521.9 & 185.6 \\
$298 \mathrm{kPa} ; 0.27 \mathrm{~m} . \mathrm{s}^{-1}$ & 51.4 & 105.1 & 441.8 & 120.5 \\
$98 \mathrm{kPa} ; 0.44 \mathrm{~m} \cdot \mathrm{s}^{-1}$ & 64.5 & 113.6 & 367.2 & 124.8 \\
$196 \mathrm{kPa} ; 0.44 \mathrm{~m} . \mathrm{s}^{-1}$ & 105.2 & 179.2 & 552.8 & 185.4 \\
$298 \mathrm{kPa} ; 0.44 \mathrm{~m} . \mathrm{s}^{-1}$ & 230.8 & 348.6 & 854.5 & 286.8 \\
\hline
\end{tabular}

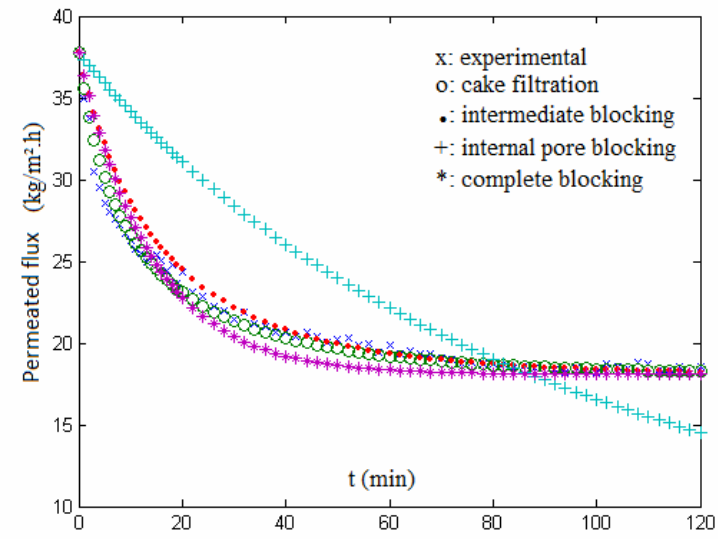

(a)

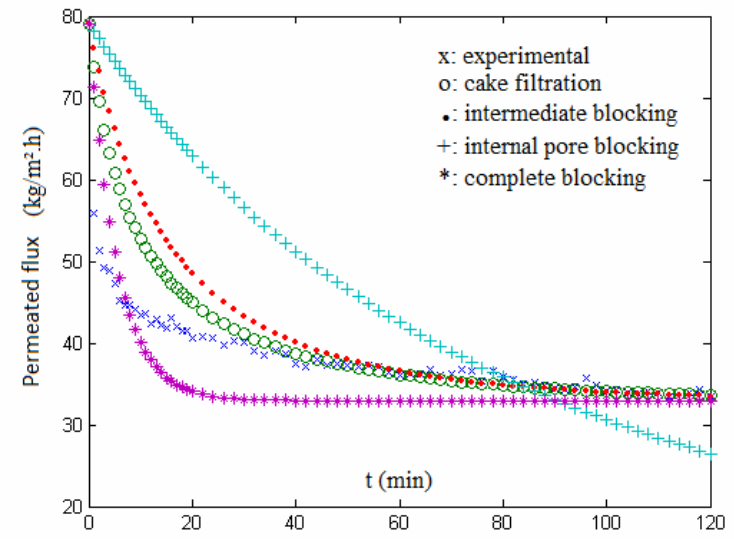

(b)

Figure 9: Results of nonlinear regression for the spiral wound membrane for identification of the pore blocking mechanism; (a) TMP: $98 \mathrm{kPa}, \mathrm{v}: 0.15 \mathrm{~m} \cdot \mathrm{s}^{-1}$; (b) TMP: $294 \mathrm{kPa}, \mathrm{v}: 0.44 \mathrm{~m} \cdot \mathrm{s}^{-1}$.

Table 9 provides the nonlinear regression results for the flux data obtained from wash water ultrafiltration tests with the tubular membrane.

Table 9 shows that no single behavior was observed in terms of pore blocking under the conditions tested using the tubular membrane. When lower cross-flow velocities $\left(0.79 \mathrm{~m} . \mathrm{s}^{-1}\right)$ were used, the cake filtration model was the best representation of the flux throughout filtration; at higher velocities $\left(1.42 \mathrm{~m} . \mathrm{s}^{-1}\right.$ and $2.23 \mathrm{~m} . \mathrm{s}^{-1}$ ), the complete pore blocking mechanism yielded the lowest sum of squares. These values serve to identify the pore blocking mechanism that best represents the experimental flux curves throughout the filtration process; however, there could be systems in which more than one mechanism might be involved. Figure 10 (a) shows the flux behavior for the tubular membrane under $98 \mathrm{kPa}$ and at $0.79 \mathrm{~m} . \mathrm{s}^{-1}$, revealing that the experimental points followed the "cake filtration" model throughout the filtration process. Figure 10 (b) illustrates the effect of cross-flow velocity; convection carries the solutes that reach the membrane, but the mass that gets to the membrane is not enough for cake formation. Thus, the solutes reduce the effective filtration area, being deposited onto the outside of the membrane. The "complete blocking" model was the one that best represented this process.

Figure 10 (c) demonstrates that the experimental points were close to those of the "complete pore blocking" model in the first periods of filtration and, as filtration proceeded, the experimental data drew closer to those of the cake filtration model, showing that pore blocking can take place in two stages. This phenomenon was reported by Bowen et al. (1995). According to these authors, there may be four stages and, due to the distribution of pore sizes in the membranes, these four stages eventually overlap.

In general, a succession of pore blocking mechanisms exists and the transition between them is gradual and separated by a narrow time interval (Bowen et al., 1995). Figure10-c illustrates this behavior, given that the experimental data were quite close to those of the complete pore blocking model during the first minutes of filtration ( $\mathrm{t}<3 \mathrm{~min})$; thereafter, at about $40 \mathrm{~min}$ of filtration the experimental data were close to those of the cake filtration model. 
Table 9: Sum of squares for the nonlinear regression of each pore blocking model assessed for the tubular membrane

\begin{tabular}{|l|c|c|c|c|}
\hline & Cake filtration & $\begin{array}{c}\text { Intermediate } \\
\text { pore blocking }\end{array}$ & $\begin{array}{c}\text { Internal } \\
\text { pore blocking }\end{array}$ & $\begin{array}{c}\text { Complete } \\
\text { pore blocking }\end{array}$ \\
\hline $98 \mathrm{kPa} ; 0.79 \mathrm{~m} . \mathrm{s}^{-1}$ & 77.8 & 332.2 & 1249.5 & 254.5 \\
$196 \mathrm{kPa} ; 0.79 \mathrm{~m} . \mathrm{s}^{-1}$ & 171.5 & 535.8 & 1687.0 & 325.7 \\
$294 \mathrm{kPa} ; 0.79 \mathrm{~m} . \mathrm{s}^{-1}$ & 273.2 & 786.2 & 1925.1 & 353.4 \\
$98 \mathrm{kPa} ; 1.42 \mathrm{~m} . \mathrm{s}^{-1}$ & 502.6 & 756.6 & 1850.7 & 235.1 \\
$196 \mathrm{kPa} ; 1.42 \mathrm{~m} . \mathrm{s}^{-1}$ & 553.9 & 926.5 & 2279.6 & 324.1 \\
$294 \mathrm{kPa} ; 1.42 \mathrm{~m} . \mathrm{s}^{-1}$ & 411.8 & 740.0 & 2230.3 & 231.1 \\
$98 \mathrm{kPa} ; 2.23 \mathrm{~m} . \mathrm{s}^{-1}$ & 555.0 & 669.4 & 1414.2 & 312.4 \\
$196 \mathrm{kPa} ; 2.23 \mathrm{~m} . \mathrm{s}^{-1}$ & 530.3 & 674.2 & 1534.6 & 503.7 \\
$294 \mathrm{kPa} ; 2.23 \mathrm{~m} . \mathrm{s}^{-1}$ & 836.3 & 1072.4 & 2042.0 & 702.3 \\
\hline
\end{tabular}

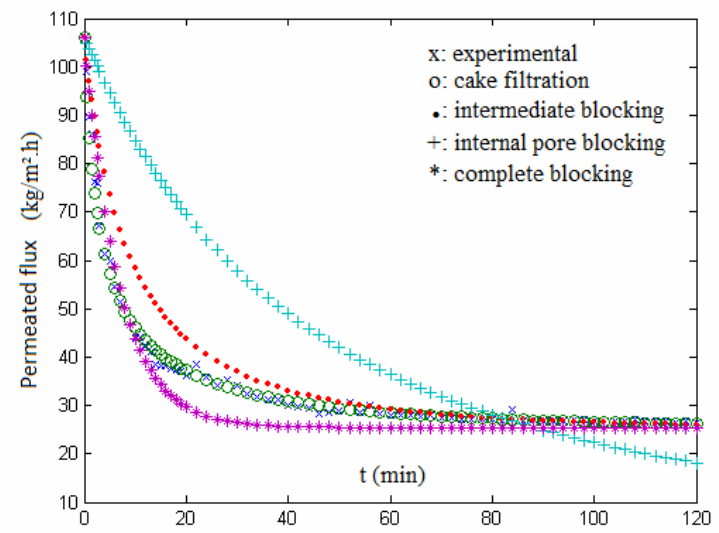

(a)

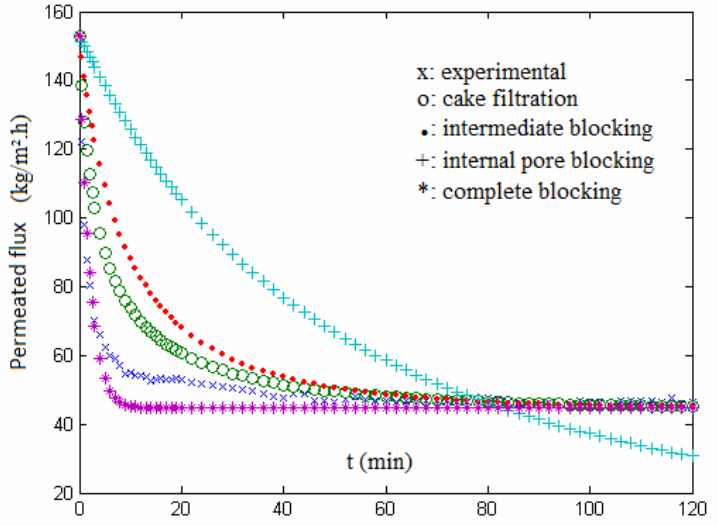

(b)

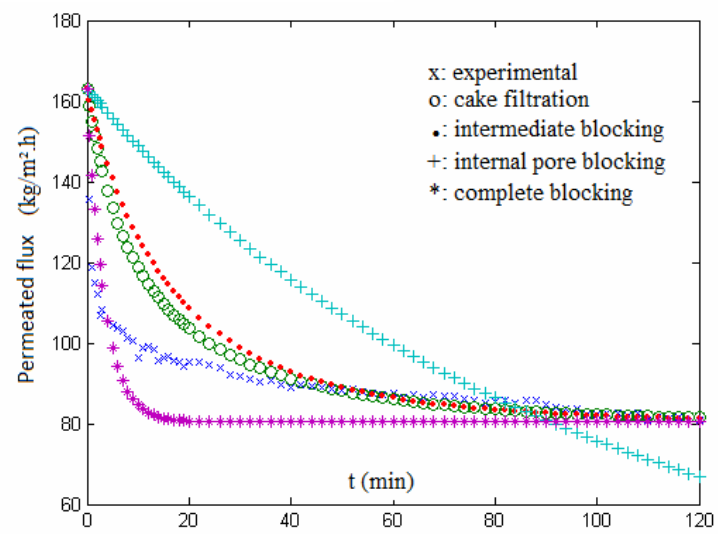

(c)

Figure 10: Results of nonlinear regression for the tubular membrane for identification of the pore blocking mechanism; (a) TMP: $98 \mathrm{kPa}, \mathrm{v}: 0.79 \mathrm{~m} \cdot \mathrm{s}^{-1}$; (b) TMP: $196 \mathrm{kPa}, \mathrm{v}: 1.42 \mathrm{~m} . \mathrm{s}^{-1}$; (c) TMP: $294 \mathrm{kPa}$, $\mathrm{v}: 2.23 \mathrm{~m} . \mathrm{s}^{-1}$

Another important aspect is that the pore blocking mechanism depends on the relationship between solute size and the diameter of the membrane pores (Herrero et al., 1997). If the solute size is much larger than the pore size, the process begins with complete blocking and, as particles deposit on those that have already adhered to the membrane, intermediate blocking predominates, followed by cake formation (Bowen et al., 1995; Prádanos et al.,
1996). Several dairy wastewater solutes have a larger size than that of the pores of both membranes (Table 3). In the spiral wound membrane, milk solids deposit or accumulate on the outside of the membrane and, owing to lower turbulence, lead to quick cake formation. In the tubular membrane, although whey proteins have a smaller size than the cut-off diameter, they account for only a small amount of the total solids in the wastewater and are found in diluted form; 
therefore, internal pore blocking was not detected in the experimental assays. Thus, complete pore blocking predominated in the initial periods of filtration. Other smaller-sized solutes, such as lactose and salts, make up the cake, but are not strongly adhered to the membrane; these compounds permeate through the membrane when such an adhered layer is not formed (Rao et al., 2002).

The resistance-in-series analysis demonstrated that milk solids deposited on the outside of the membranes. On the other hand, the two pore blocking mechanisms identified (complete blocking and cake formation) are also membrane external blocking mechanisms and thus both analysis are in agreement with this finding.

A two-step pore blocking process was not observed when low cross-flow velocities were applied to the tubular membrane filtration. Basically, the drag effect of the convective flux exerted on the molecules that reached the membrane was so small that, from the outset, the balance of forces of these molecules caused them to deposit on the membrane surface, leading to quick cake formation. Likewise, higher pressures produced an increase in initial flux $\left(\mathrm{J}_{0}\right)$, heightening convective transport to the membrane and accelerating cake formation.

\section{CONCLUSIONS}

The resistance-in-series analysis showed that there was external pore blocking in both membranes, with deposition and/or adsorption of solutes only on the membrane surface. Deposit resistance contributed more substantially to reducing the tubular membrane flux (about $80 \%$ of the total resistance), whereas for the spiral wound membrane, the reversible and irreversible resistances averaged $41 \%$ and $45 \%$, respectively.

The "cake filtration" model was the best representation of pore blocking in dairy wastewater ultrafiltration with the spiral wound membrane.

As for the tubular membrane, no single behavior in terms of pore blocking was representative of its permeated flux, especially with regard to the crossflow velocity used. At the lowest cross-flow velocity $\left(0.79 \mathrm{~m} . \mathrm{s}^{-1}\right)$, the cake formation model fitted best to the experimental data. However, at higher cross-flow velocities, the best fit of the flux data was obtained with the complete pore blocking model, due to the convective drag effect and to the removal of the external layer of solutes formed on the membrane.

The analysis of intermediate $\left(1.42 \mathrm{~m} \cdot \mathrm{s}^{-1}\right)$ and upper $\left(2.23 \mathrm{~m} . \mathrm{s}^{-1}\right)$ ranges of cross-flow velocity revealed that the tubular membrane pore blocking followed a sequence of mechanisms, with an initial flux decrease due to complete pore blocking, followed by a transition region, with subsequent cake formation.

\section{NOMENCLATURE}

\begin{tabular}{|c|c|}
\hline A & membrane surface \\
\hline COD & Chemical Oxygen Demand \\
\hline $\mathrm{J}$ & Permeate flux \\
\hline $\mathrm{J}^{*}$ & $\begin{array}{l}\text { critical flux in Equations } \\
\text { (6)-(10) }\end{array}$ \\
\hline $\mathrm{J}_{\mathrm{w}}$ & $\begin{array}{l}\text { pure water flux after rinsing } \\
\text { the membrane }\end{array}$ \\
\hline $\mathrm{J}_{\mathrm{o}}$ & initial permeate flux at $\mathrm{t}=0$ \\
\hline $\mathrm{J}_{\mathrm{w}}$ & $\begin{array}{l}\text { pure water flux before } \\
\text { running the experiment }\end{array}$ \\
\hline
\end{tabular}

$\mathrm{k}_{1}$

constant of Hermia's model for intermediate blocking

$\mathrm{k}_{\mathrm{a}} \quad$ constant of complete pore blocking

$\mathrm{k}_{\mathrm{b}} \quad$ constant of internal pore blocking

$\mathrm{k}_{\mathrm{c}} \quad$ constant of intermediate pore blocking

$k_{d} \quad$ constant of cake filtration model

$\mathrm{k}_{\mathrm{t}} \quad$ cake filtration constant relating cake mass to permeate volume

MWCO Molecular Weight Cut Off

$\mathrm{n}$ index of Hermia's model dimensionless

PES polyethersulfone

PVDF polyvinylidene fluoride

Q volumetric flowrate

$\mathrm{R}$ total resistance

$\mathrm{R}_{\text {ir }} \quad$ resistance indicates

irreversible fouling

$\mathrm{R}_{\mathrm{m}} \quad$ membrane resistance

$\mathrm{R}_{\mathrm{r}} \quad$ resistance indicates

reversible fouling and concentration polarization

$\mathrm{t}$ time$$
\text { TMP transmembrane pressure }
$$$$
\mathrm{V} \text { permeate volume }
$$$$
\text { v cross-flow velocity }
$$

$$
\begin{gathered}
\mathrm{m}^{3} \cdot \mathrm{s}^{-1} \\
\mathrm{~m}^{-1} \\
\mathrm{~m}^{-1} \\
\mathrm{~m}^{-1} \\
\mathrm{~m}^{-1} \\
\\
\mathrm{~s} \\
\mathrm{~Pa} \\
\mathrm{~m}^{3} \\
\mathrm{~m} \cdot \mathrm{s}^{-1}
\end{gathered}
$$

unit depends

on the pore

blocking

$$
\mathrm{m}^{-3 / 2} \cdot \mathrm{s}^{1 / 2}
$$

dimensionless

$\mathrm{m}^{-1 / 2} \cdot \mathrm{s}^{1 / 2}$

$\mathrm{m}^{-1}$

s. $\mathrm{m}^{-2}$

kg. $\mathrm{m}^{-3}$ 


\section{Greek Letters}

$\begin{array}{llr}\mu & \text { permeate viscosity } & \text { Pa.s } \\ \mu_{\mathrm{w}} & \text { pure water viscosity } & \text { Pa.s } \\ \alpha & \text { specific cake resistance } & \mathrm{m} . \mathrm{kg}^{-1} \\ \varepsilon_{0} & \text { membrane surface porosity } & \text { dimensionless } \\ \sigma & \text { blocked area per unit } & \mathrm{m}^{-1} \\ & \text { volume of filtrate } & \end{array}$

\section{REFERENCES}

Argüello, M. A., Álvarez, S., Riera, F. A., Álvarez, R., Enzymatic cleaning of inorganic ultrafiltration membranes fouled by whey proteins. Journal of Agricultural and Food Chemistry, 50, 1951-1958 (2002).

Arnot, T. C., Field, R. W., Koltuniewicz, A. B., Cross-flow and dead-end microfiltration of oilywater emulsions. Part II: Mechanisms and modeling of flux decline. Journal of Membrane Science, 169, 1 -15 (2000).

Barros, S. T. D., Andrade, C.M.G., Mendes, E. S., Peres, L., Study of fouling mechanism in pineapple juice clarification by ultrafiltration. Journal of Membrane Science, 215, 213-224 (2003).

Baskaran, K., Palmowski, L. M., Watson, B. M., Wastewater reuse and treatment options for the dairy industry. Water Science \& Technology, 3, n. 3, 85-91 (2003).

Baudry, M. R., Maux, M. L., Chaufer, B., Begoin, L., Characterisation of cleaned and fouled membrane by ATR-FTIR and EDX analysis coupled with SEM: application to UF of skimmed milk with a PES membrane. Desalination, 146, 123-128 (2002).

Blanpain, P., Lalande, M., Investigation of fouling mechanisms governing permeate flux in the crossflow microfiltration of beer. Filtration and Separation, 34, n. 10, 1065-1069 (1997).

Bowen, W. R., Calvo, J. I., Hernández, A., Steps of membrane blocking in flux decline during protein microfiltration. Journal of Membrane Science, 101, 153-165 (1995).

Brião, V. B. and Tavares, C. R. G., Effluent generation by the dairy industry: preventive attitudes and opportunities. Brazilian Journal of Chemical Engineering, 24, n. 4, 487-497 (2007).

Brião, V. B. and Tavares, C. R. G., Ultrafiltração como processo de tratamento para o reuso de efluentes de laticínios. Engenharia Sanitária e Ambiental, 12, n. 2, 134-138 (2007a). (In Portuguese).
Brião, V. B., Study of wastewater pollution prevention in a dairy industry. Master thesis, State University of Maringa (2000).

Chang, In-Soung, Kim, Su-Na., Wastewater treatment using membrane filtration - effect of biosolids concentration on cake resistance. Process Biochemistry, 40, 1307-1314 (2005).

Cheryan, M., Ultrafiltration and microfiltration handbook. Technomic, Lancaster (1998).

Choi, H., Zhang, K., Dionysiou, D., Oerther, D. B., Sorial, G. A., Effect of permeate flux and tangential flow on membrane fouling for wastewater treatment. Separation and Purification Technology, 45, n. 1, 68-78 (2005).

Clarke, T. E., Heath, C. A., Ultrafiltration of skim milk in flat-plate and spiral-wound modules. Journal of Food Engineering, 33, 373- 83 (1997).

Field, R. W., Wu, D., Howell, J. A., Gupta, B. B., Critical flux concept for microfiltration fouling. Journal of Membrane Science, 100, 259-272 (1995).

Gésan-Guisiou, G., Boyaval, E., Daufin, G., Critical stability condition in crossflow microfiltration of skimmed milk: transition to irreversible deposition. Journal of Membrane Science, 158, 211-222 (1999).

Hermia, J., Constant pressure blocking filtration laws - application to power-law non-newtonian fluids. Icheme, 60, 183-187 (1982).

Herrero, C., Pradános, P., Calvo, J. I., Tejerina, F., Hernandez, A. Flux decline in protein microfiltration: influence of operative parameters. Journal of Colloid and Interface Science, 87, 344-351 (1997).

Huisman, I. H., Elzo, D., Middelink, E., Trägardh, A. C. Properties of the cake layer formed during crossflow microfiltration. Colloids and Surfaces, A, 138, 265-281 (1996).

Hwang, K., Lin, T., Effect of morphology of polymeric membrane on the performance of cross-flow microfiltration. Journal of Membrane Science, 199, 41-52 (2002).

Jacob, J., Prádanos, P., Calvo, J. I., Hernandez, A., Jonsson, G., Fouling kinetics and associated dynamics of structural modifications. Colloids and Surfaces, A, 138, 173-183 (1998).

Jaffrin, M. Y., Ding, L. H., Couvreur, C., Khari, P., Effect of ethanol on ultrafiltration of bovine albumin solutions with organic membranes. Journal of Membrane Science, 124, 233-241 (1997).

James, B. J., Jyng, Y., Cheng, X. D., Membrane Fouling during filtration of milk - a microstructural study. Journal of Food Engineering, 60, 431-437 (2003).

Jonsson, A., Trägardh, G., Ultrafiltration Applications. Desalination, 77, 137-179 (1990). 
Jonsson, G., Prádanos, P., Hernandez, A., Fouling phenomena in microporous membranes, flux decline kinetics and structural modifications. Journal of Membrane Science, 112, 171-183 (1996).

Li, M., Zhao, Y., Zhou, S., Xing, W., Clarification of raw rice wine by ceramic microfiltration membranes and membrane fouling analysis. Desalination, 256, n. 1-3, 166-173 (2010).

Matthiasson, E., Sivik, B., Concentration polarization and fouling. Desalination, 35, 59-103 (1980).

Merin, U., Shomer, I., Ultrafiltration of Heat-treated Shamouti Orange [Citrus sinensis (L.) Osbeck] Juice. Journal of Agricultural and Food Chemistry. American Chemical Society, 47, 2617-2622 (1999).

Peppin, S. S. L., Elliot, J. A. W., Non-equilibrium thermodynamics of concentration polarization. Advances in Colloid and Interface Science, 92, 172 (2001).

Rao, R. H. G., Mechanisms of flux decline during ultrafiltration of dairy products and influence of $\mathrm{pH}$ on flux rates of whey and buttermilk. Desalination, 144, 319-324 (2002).

Rezaei, H., Ashtiani, F. Z., Fouladitajar, A., Effects of operating parameters on fouling mechanism and membrane flux in cross-flow microfiltration of whey. Desalination, 274, n. 1-3, 262-271 (2011).

Song, L., Flux decline in crossflow microfiltration and ultrafiltration: mechanisms and modeling of membrane fouling. Journal of Membrane Science, 139, 183-200 (1998).

Timmer, J. M. K., van der Horst, H. C., Labbé, J. P., Cross-flow microfiltration of $\beta$-lactoglobulin solutions and the influence of silicates on the flow resistance. Journal of Membrane Science, 136, 41-56 (1997).

Tracey, E., Davis, R. H., Protein fouling of tracketched polycarbonate microfiltration membranes. Journal of Colloid and Interface Science, 167, 104-116 (1994).

van Boxtel, A. J. B., Otten, Z. E. H., van der Linden, H. J. L. J., Evaluation of process models for fouling control of reverse osmosis of cheese whey. Journal of Membrane Science, 58, 89-111 (1991).

Vela, M. C., Silvia, V., Blanco, Á., García, J. L., Rodríguez, E. B., Fouling dynamics modeling in the ultrafiltration of PEGs. Desalination, 222, n. 1-3, 451-456 (2008).

Vourch, M., Balannec, B., Chaufer, B., Dorange, G., Nanofiltration and reverse osmosis of model process waters from the dairy industry to produce water for reuse. Desalination, 172, 245-256 (2005).

Vourch, M., Balannec, B., Chaufer, B., Dorange, G., Treatment of dairy industry wastewater by reverse osmosis for water reuse. Desalination, 219, 190-202 (2008).

Yazdanshenas, M., Soltanieh, M., Nejad, S. A. R. T., Fillaudeau, L., Cross-flow microfiltration of rough non-alcoholic beer and diluted malt extract with tubular ceramic membranes: Investigation of fouling mechanisms. Journal of Membrane Science, 362, n. 1-2, 306-316 (2010).

Ye, Y., Clech, P. L., Chen, V., Fane, A. G., Jefferson, B. Fouling mechanisms of alginate solutions as model extracellular polymeric substances. Desalination, 175, n. 1, 7-20 (2005). 